\title{
3D nyomtatható biokompatibilis modell alapanyagok polimerizációs tulajdonságainak vizsgálata
}

\author{
DR. SZALÓKI MELINDA*, HAMID JAVADI*, SARA KHANDAN*, ADELINA YOUSSEF STEPHANIE*,
} DR. GÁLL JÓZSEF**, DR. HEGEDÜS CSABA*

\begin{abstract}
A 3D nyomtatás pontosságát sok tényező befolyásolja, többek között a nyomtatáshoz használt polimerek összetétele, amely a polimerizációs paramétereket, a polimerizációs zsugorodást (PS) és konverziót (DC) befolyásolja. A munkánk során két kereskedelmi forgalomban kapható biokompatibilis 3D nyomtatható anyag PS és DC értékeit vizsgáltuk. Ezekre a paraméterekre nincs adat az irodalomban. Jelen kutatás célja megvizsgálni, hogy a vizsgált polimerek polimerizációs paraméterei hogyan változnak a nyomtatás utáni öt napig, mely utópolimerizációs folyamatok hatással lehetnek a kinyomtatott modellek dimenzióbeli torziós paramétereire. Vizsgálataink alapján megállapítottuk, hogy a polimerek PS értékei első mérési naptól az ötödik napig szignifikánsan növekedtek; 0,2271 v/v\%-kal a MED610 és 0,4979 v/v\%-kal a MED620 esetén. A DC értékek 90,182 és 99,9433\% között változtak és a 3. napon mutattak maximumot. A MED610 polimer esetén kisebb mértékű volt a polimerizációs paraméterek változása, mint MED620 esetén, így utóbbi esetén nagyobb mértékű utópolimerizációs hatással kell számolni, mely befolyásolhatja a kinyomtatott objektum pontosságát.
\end{abstract}

Kulcsszavak: MED610, MED620, 3D nyomtatható biokompatibilis polimer, polimerizációs zsugorodás, polimerizációs konverzió.

\section{Bevezetés}

A 3D nyomtatási technológia és a digitális szkennerek fogászat területén történő megjelenése nagymértékben lecsökkenti pl. a fogpótlások elkészítési munkafolyamatainak hosszát [19]. Többféle 3D nyomtatási technológia létezik, melyek az objektumok, a 3 dimenziós testet felépítő rétegek kialakításában, nyomtatáshoz használt alapanyagokban is különbözhetnek. A sztereolitográfia (SLA), szelektív lézeres szinterelés (Selective Laser Sintering, SLS), szálextrúziós technológia (huzalolvasztásos technika; Fused Deposition Modeling, FDM) fotopolimer Jetting (PolyJet) és a Digital Light Processing (DLP) az alkalmazott módszerek fogászati pótlások készítésében [24, 28]. A sztereolitográfiás módszer fotopolimerizáció elven működő technológia. Fotoiniciátort tartalmazó gyantakeverék egy tartályban található, amelybe tükrökkel pozícionált, fókuszált lézersugár segítségével a gyanta térhálósítása megy végbe a folyadékban.

A Polymer Jetting (röviden PolyJet) gyakran alkalmazott technológia, mely szintén fotopolimerizációval alakítja ki a testet felépítő rétegeket azzal a különbséggel, hogy a gyanta - fotoiniciátor keveréket egy nyomtatófej adagolja a munkaasztalra a támaszanyaggal együtt. A gyantakeverék és a támaszanyag UV lámpa segítségével polimerizálódik. Ez a technológia is, hasonlóan az SLA-hoz, rövid nyomtatási idővel, jó minőségú, sima felületú, magas felbontású, kis polimerizációs zsugorodással rendelkező testeket eredményez. A polimer kémiai struktúrájának változtatásával vagy nanoméretú töltőanyag hozzáadásával a nyomtatott termék mechanikai tulajdonsága befolyásolható, amely ezen technológia alkalmazási területének határait tolja ki [20].

A digitális munkafolyamat során az első lépés a digitális file elkészítése, melyet a 3D nyomtató tervező szoftvere kezelni tud. Ez történhet egy digitális szkenner használatával vagy Cone Beam CT felvétel elkészítésével. A CT által készített DICOM file STL file-ba történő konvertálása során számolnunk kell adatvesztéssel [29], mely a nyomtatott objektum eredeti, tervezett méretekhez viszonyított torzulásához vezet [13, 23]. Ezek mellett a nyomtatók is rendelkeznek egy adott pontossággal [1,16], illetve a nyomtatás utáni sterilizálás is okozhat torziót a kinyomtatott objektum paramétereiben [22]. A PolyJet technikában használt fotoszenzitív anyagok $[3,15]$ UV fénnyel történő megvilágítás polimerizációja során, hasonlóan a fogászati tömőanyagok gyanta-fázisának polimerizációjához, számolni kell a polimerizációs zsugorodás fellépésével. A zsugorodást mint térfogat kontrakciót, az olyan precíziós területek, mint a fogászat és a digitális munkafolyamatok, hátrányos tulajdonságként kell számon tartani. A polimerizációs zsugorodás mellett a másik fontos polimerizációs paraméter a po- 
limerizációs konverzió. A konverzió a monomerekben megtalálható reaktív csoportjainak $(\mathrm{C}=\mathrm{C}$ kettős kötések) elreagálást fejezi ki a kiindulási állapothoz viszonyítva. A 3D nyomtatóban végbement polimerizáció után az objektumban maradt el nem reagált monomerek további reakcióba léphetnek, a szabad gyökök mozgékonyságától függően, továbbépítve a térhálós szerkezetet. A polimerizáció a besugárzás után akár 24 órával is folytatódhat, amit post polimerizációs vagy utópolimerizációs folyamatnak neveznek [27].

A munka célja a 3D nyomtatható polimer polimerizációs zsugorodás és konverzió értékeinek vizsgálata, melyek információt adhatnak a nyomtatás utáni utópolimerizáció mértékéről, így ezen anyagoknak a fogászati alkalmazhatóságáról.

\section{Vizsgálati anyag és módszer}

\subsection{Biokompatibilis $3 D$ nyomtatható polimerek nyomtatása és felületkezelése}

Ebben a tanulmányban két, 3D nyomtatható, gyári ismertető szerint biokompatibilis polimer [7], a MED620 (Stratasys, USA) és MED610 (Stratasys, USA) polimerizációs paraméterei voltak vizsgálva. A polimer minták 3D tervezése Object Studio tervező programmal, nyomtatásuk Objet30 OrthoDesk (Stratasys, USA) 3D nyomtató használatával történt. Az objektumok nyomtatása után a SUP705 (Stratasys, USA) támaszanyag a gyártó utasítása szerint volt eltávolítva, amely többlépéses tisztítási folyamatból áltt [10]. Első lépésben a támaszanyag mechanikai eltávolítása történik nagy nyomású vízborotvával (Stratasys, USA). Ezután egy oldószeres kezelés következik, mely 3 órás $1 \mathrm{~m} / \mathrm{m} \%$-os $\mathrm{NaOH}$ (VWR, Magyarország) és 30 perces 2-propanol (VWR, Magyarosrszág) oldatokban történő áztatásból állt. Az alkoholos áztatás után a minták szobahőmérsékleten száradtak. A gyártó szerint a MED610 és MED620 a következő komponensekből áll biztonságtechnikai adatlapja szerint [8] (1. táblázat):

1. táblázat

\section{MED610 és MED620 anyagbiztonsági adatlapjában} megjelölt összetevők.

\begin{tabular}{|l|l|}
\hline MED610 & MED620 \\
\hline izobornil akrilát, akrilát & akrilát típusú monomer, \\
típusú monomer, uretán & 2-propánsav- [(1S,4S)-1,7,7- \\
akrilát, epoxi akrilát, akrilát & trimetil-2-norbornanil] észter, \\
oligomer, fotoiniciátor & akrilát oligomer, titán-dioxid \\
részecskék, akrilsav észter, \\
xilol (izomerek keveréke), \\
n-butil acetát, etil-benzol, \\
foszforsav, propilén glikol \\
& monometil éter acetát, \\
& foszforsav, fotoiniciátor \\
\hline
\end{tabular}

A MED610 alapanyag például implantációs és ortodonciai alkalmazásra (orthodontic appliances) [5, 6, 11, 25], míg a MED620-ból elsősorban modellek készítésére használható a gyártó cég javaslata alapján. Mindkét anyag számos biokompatibilitási (citotoxicitás, genotoxicitás, hiperszenzitivitás) szabvány által meghatározott követelményeknek is megfelel. A gyártó szájnyálkahártyával történő érintkezés esetén 24 órás, míg bőrrel akár 30 napos érintkezés is engedélyezett az FDA (Food and Drug Administration) engedélyével.

\subsection{Polimerizációs zsugorodás meghatározása}

A polimerizációs zsugorodás (Polymerization Shrinkage, röviden PS) meghatározásához kocka alakú blokkok voltak nyomtatva $10 \mathrm{~mm} \times 10 \mathrm{~mm}$ méretben, magasságuk $5 \mathrm{~mm}$ volt (1. kép).

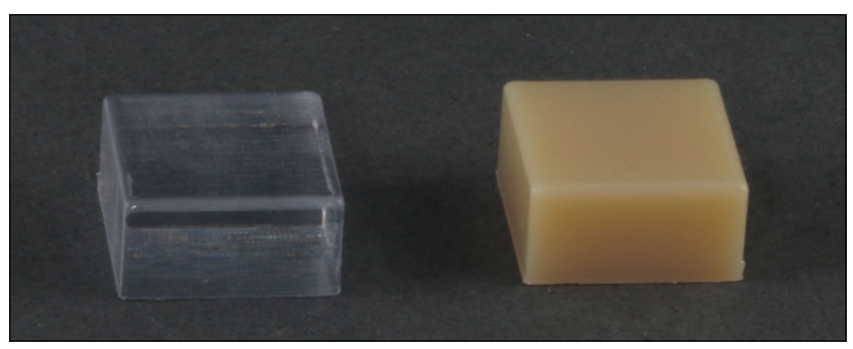

1. kép: Polimerizációs zsugorodás meghatározásához nyomtatott próbatestek biokompatibilis polimerekből

(balra: áttetsző MED610, jobbra: MED620 Vita A2 színben)

A MED610 és MED620 mintákból 15-15 próbatest volt nyomtatva. A polimerizációs zsugorodást analitikai mérlegre (Adam Equipment PW 254, UK) szerelhető súrűség meghatározó feltéttel volt meghatározva desztillált vízben kontrollált hőmérséklet $\left(22 \pm 2{ }^{\circ} \mathrm{C}\right)$ és $50 \%$ relatív páratartalom mellett (DIN 13907) [26]. A minták térfogatos változása a nyomtatás után 5 napig, napi méréssel volt követve. A minták szobahőmérsékleten, száraz labor körülmények között voltak tárolva. A nyomtatás után és az első mérési nap között mindkét polimernél ugyanannyi nap telt el. Az Archimedesz törvénye szerinti mérési módszer alapja a sűrűség-változás, amely fotopolimerizáció alatt történik. Ez a sürüség-változás térfogatos formában kifejezve $(V=m / \rho)$ és a következő képlet használatával volt meghatározva:

$$
\text { PS }\left(\frac{V}{V} \%\right)=\frac{V_{\text {polim.elött }}-V_{\text {polim.után }}}{V_{\text {polim.előtt }}} * 100
$$

ahol $V_{\text {polim. elótt }}$ a minta térfogatát jelöli polimerizáció előtt, a $V_{\text {polim. után }}$ a minta térfogata polimerizáció után. Polimerizáció elótti minta térfogata a polimerizálatlan gyanta térfogatával egyezik meg.

\subsection{Polimerizációs konverzió meghatározása}

A polimerizációs konverzió (Degree of Conversion, röviden DC) Nicolet 6700 Fourier Transzformációs Infravörös Spektrométerrel (Thermo Electron Co. USA) csillapított teljes reflexiós (Attenuated Total Reflectance mode, ATR) módban volt mérve 5 napig, napi mérések- 
kel, követve az utópolimerizációs folyamatokat. A DC százalékban kifejezett értékei a következő képlet alapján voltak számolva:

$$
D C(\%)=\frac{\frac{A_{\text {polimer alifás }}}{A_{\text {polimer belső standard }}}}{\frac{A_{\text {monomer alifás }}}{A_{\text {monomer belső standard }}}} * 100
$$

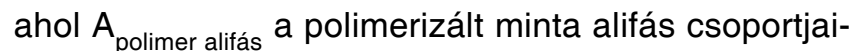
nak abszorbanciája; $A_{\text {polimer belső standard }}$ a polimer láncban belső standardnak tekintett $\mathrm{C}=\mathrm{O}$ karboxil csoportok abszorbancia értékei; $A_{\text {monomer alifás }}$ a monomer keverék alifás csoportjainak abszorbanciája; $A_{\text {monomer }}$ belsö standard a monomerben belső standardnak tekintett $\mathrm{C}=\mathrm{O}$ karboxil csoportok abszorbancia értékei. $\mathrm{A}$ belső standardként választott $\mathrm{C}=\mathrm{O}$ funkciós csoportok abszorbancia értékei nem változnak a polimerizáció alatt. Az alifás csoportok rezonancia hullámszám értékei $1637 \mathrm{~cm}^{-1}$, míg a karboxil csoportoké $1715 \mathrm{~cm}^{-1}$ [4].

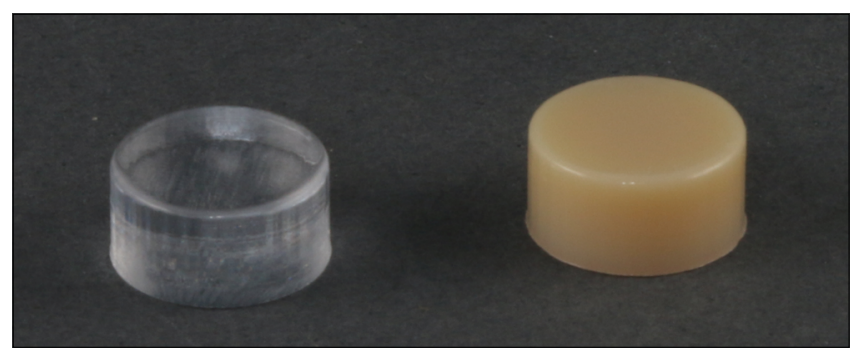

2. kép: Kezelés előtti CT felvétel, melyen a jobb maxilla oszteolítikus léziójával összefüggésben lévő összeesett jobb oldali arcüreg, és a jobb orbita laterális fala keményszöveteinek lágyrészes helyettesítés látható.

5 korong alakú próbatest volt nyomtatva a MED610 polimerből és 7 próbatest a MED620-ból (2. kép). Az A2 árnyalatú MED620 töltőanyagot is tartalmaz, amely az ATR módban mért IR mérésekben zavaró tényezőként jelenhet meg. A próbatestek átmérője $10 \mathrm{~mm}$, vastagsága $5 \mathrm{~mm}$ volt. Az 5 napos periódus alatt minden minta egyszer volt megmérve, ahol minden mérési pont 16 spektrum átlaga alapján került kiértékelésre. A minták szobahőmérsékleten, száraz labor körülmények között voltak tárolva.

\subsection{Statisztikai elemzés}

Két különböző t-próba volt használva az adatok statisztikai elemzésében. Független mintás t-próba a PS és DC átlagértékek összehasonlítására a MED610 és MED620 polimer esetén. Páros mintás t-próba 1. és 5 . napon mért átlagok összehasonlítására. A szignifikancia limitet a polimerizációs zsugorodás méréseknél $(n=15$ MED610 és MED620 esetén) 5\%-nak, a konverziós méréseknél $10 \%$-nak választottuk a kis elemszám miatt $(n=5$ MED610 és $\mathrm{n}=7$ MED620 esetén). A statisztikai analízisekhez SPSS 17.0 statisztikai szoftvert használtuk.

\section{Eredmények}

\subsection{Polimerizációs zsugorodás (PS) MED610 és MED620 polimer esetén}

A MED610 és MED620 polimer minták polimerizációs zsugorodás átlagértékeit ábrázolva mutatja a 3. kép. A PS értékek folyamatosan nőttek az 1 . naptól az 5. napig mindkét polimer esetén. A MED610 polimer nagyobb kezdeti (1. nap) zsugorodást mutatott a polimerizálatlan gyanta értékére vonatkoztatva, mint a MED620. Ezt a magasabb PS értéket a MED610 végig tartotta az ötnapos vizsgálat alatt.

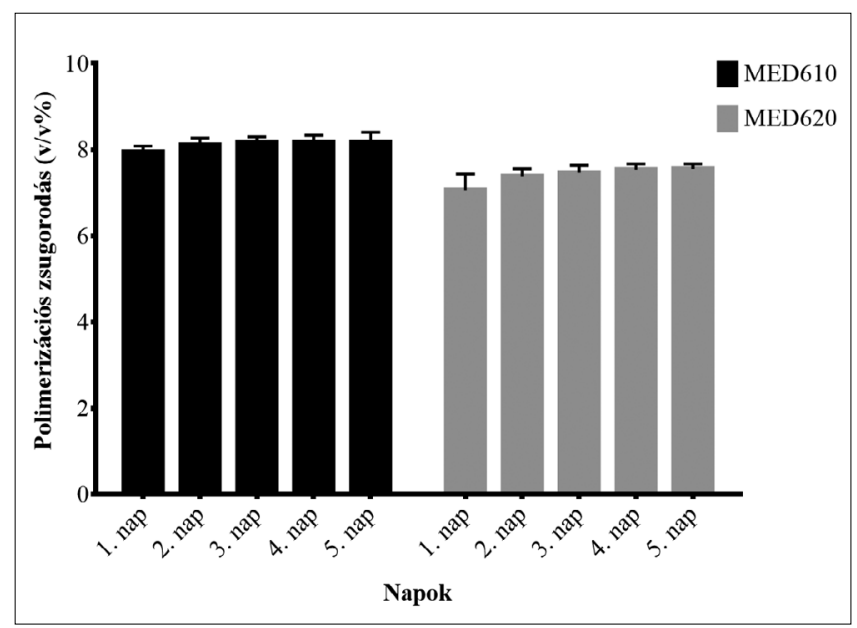

3. kép: Polimerizációs zsugorodás átlagértékek 1-5 napokon MED610 és MED620 3D nyomtatható polimerek esetén.

A MED610 és MED620 zsugorodás értékeinek leíró statisztikáját összegzi az 2. táblázat.

2. táblázat

A MED610 és MED620 zsugorodás ( $v / v \%$ ) értékeinek leíró statisztikája

\begin{tabular}{|l|c|c|c|c|c|}
\hline \multicolumn{2}{|c|}{} & $\mathrm{n}$ & Átlag & Szórás & Standard hiba \\
\hline 1. nap & MED 610 & 15 & 7,9433 & 0,14171 & 0,03659 \\
\hline & MED 620 & 14 & 7,0619 & 0,37444 & 0,10007 \\
\hline 2. nap & MED 610 & 15 & 8,1085 & 0,16177 & 0,04177 \\
\hline & MED 620 & 15 & 7,3830 & 0,18005 & 0,04649 \\
\hline 3. nap & MED 610 & 15 & 8,1601 & 0,13914 & 0,03593 \\
\hline & MED 620 & 15 & 7,4662 & 0,17332 & 0,04475 \\
\hline 4. nap & MED 610 & 15 & 8,1704 & 0,16436 & 0,04244 \\
\hline & MED 620 & 15 & 7,5390 & 0,13365 & 0,03451 \\
\hline 5. nap & MED 610 & 15 & 8,1704 & 0,23500 & 0,06068 \\
\hline & MED 620 & 15 & 7,5598 & 0,11491 & 0,02967 \\
\hline
\end{tabular}

A táblázat adatai alapján látható, hogy a zsugorodás-értékek nagyobb mértékben változtak a MED620 esetén. Az első napról az ötödikre 0,4979 v/v\%-os (7,0619 v/v\%ról 7,5598 v/v\%-ra), míg a MED610 esetén 0,2271 v/v\% PS növekedés (7,9433 v/v\%-ról 8,1704 v/v\%-ra) volt megfigyelhető. Ezek alapján megállapítható, hogy 
a MED620 esetén a 3D nyomtatása utáni utópolimerizációs hatások jelentősebb mértékben zajlanak a polimerben, mint a MED610 esetén.

$A z$ 1. és 5. napi átlag zsugorodás-értékek statisztikai eredményei azt mutatták, hogy szignifikáns növekedés következik be az ötnapos periódus alatt, mind a MED610, mind a MED620 esetén.

\subsection{Polimerizációs konverzió (DC) MED610 és MED620 polimer esetén}

A MED610 és MED620 polimerizációs konverziós átlagértékeit mutatja a 4. kép. A DC értékek a napok elörehaladtával növekedtek a 3. napig, amely alapján azt feltételezhető, hogy a polimerben maradt el nem reagált monomerek utólagosan részt vesznek olyan reakciókban, melyek növelik a polimerizált minta alifás csoportjainak abszorbanciáját, növelve ezzel a DC értéket.

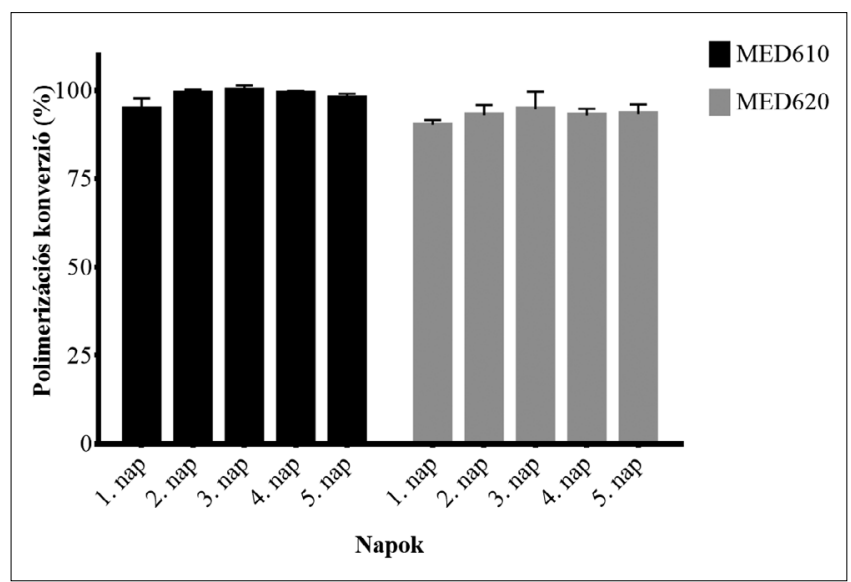

4. kép: Polimerizációs konverzió átlagértékek 1-5 napokon MED610 és MED620 3D nyomtatható polimerek esetén.

A 3. táblázat összegzi a MED620 és MED610 polimerizációs konverziós vizsgálatának leíró statisztikáját. A konverziós értékek elég magasak, egy töltőanyag gyanta fázisának konverziós értékeihez viszonyítva [2],

3. táblázat

A MED610 és MED620 polimerizációs konverzió (\%) értékeinek leíró statisztikája

\begin{tabular}{|l|c|c|c|c|c|}
\hline \multicolumn{2}{|c|}{} & $\mathrm{n}$ & Átlag & Szórás & Standard hiba \\
\hline 1. nap & MED 610 & 5 & 94,7326 & 3,06379 & 1,37017 \\
\hline & MED 620 & 7 & 90,1820 & 1,43714 & 0,54319 \\
\hline 2. nap & MED 610 & 5 & 99,1827 & 1,02054 & 0,45640 \\
\hline & MED 620 & 7 & 93,0122 & 2,83752 & 1,07248 \\
\hline 3. nap & MED 610 & 5 & 99,9433 & 1,56705 & 0,70081 \\
\hline & MED 620 & 7 & 94,7169 & 4,98732 & 1,88503 \\
\hline 4. nap & MED 610 & 5 & 99,2056 & 0,63918 & 0,28585 \\
\hline & MED 620 & 7 & 92,9918 & 1,77031 & 0,66912 \\
\hline 5. nap & MED 610 & 5 & 97,7580 & 1,30702 & 0,58452 \\
\hline & MED 620 & 7 & 93,3380 & 2,66126 & 1,00586 \\
\hline
\end{tabular}

vélhetően a kis rétegvastagságnak köszönhető, amely a gyártói leírás szerint minimum 28 mikrométer [9]. A MED620 esetén kisebb konverziós értékek voltak mérve, mint a MED610 esetén, amely az összetételbeli különbséggel, töltőanyag jelenlétével magyarázható. A napi átlag DC értékek kis mértékben különböztek egymástól, egyes esetben a különbségek a szórásokkal voltak összevethetők.

$A z$ 1. és 5. napi átlag konverziós értékek összehasonlításának páros mintás t-próba eredményei azt mutatták, hogy a polimerizációs konverzióértékek szignifikánsan növekedtek az 5 napra felállított 10\% szignifikancia limit alapján (MED610 esetén $p=0,058$; MED620 esetén $p=0,003)$. Az 1. és 3 . napi átlag DC értékek is szignifikáns növekedést mutattak (MED610 esetén $p=0,039$; MED620 esetén $p=0,049$ ).

Összességében megállapítható: a PS és DC polimerizációs értékek változnak a vizsgálati 5 napos periódus alatt mindkét polimer esetén. A PS értékek folyamatosan növekedtek az 5 napos vizsgálat alatt, a DC értékek maximumot mutattak a 3. napon. Az 5. napon mért polimerizációs paraméter értékek szignifikánsan magasabb értékeket mutattak az első nap (konverzió esetén a 3. nap is) értékeihez viszonyítva. A polimerizációs paraméterek változása az utópolimerizációs folyamatok jelenlétét igazolja.

\section{Megbeszélés}

A 3D nyomtatási technológiák csoportjában, a fotopolimerizáció elvén működő módszerekben fotoszenzitív polimerek és azok kompozitjai használatosak. A mátrix többféle komponens keverékéből épül fel, melyet a gyártók úgy alkotnak meg, hogy annak viszkozitása, reaktivitása, mechanikai tulajdonságai és a polimerizációval kialakult struktúra a célnak megfelelő legyen. A 3D nyomtatás nagyfokú pontosságot követel a fogászati felhasználás során, így dimenzióbeli torzulásával foglalkozni kell, amely többek között a polimerizációs zsugorodás következménye is lehet. Rebong és munkatársai által végzett vizsgálatban 3 ortodonciában leggyakrabban használt 3D nyomtatási technikát (FDA, SLA és PolyJet) hasonlítottak össze [20]. A gipszmodellhez viszonyítva mindhárom technikával találtak különbséget. Az SLA és a Polyjet technikával nyomtatott modellek csökkenő tendenciát mutattak vertikális dimenzióban a meghatározott pontok távolságában. Ezzel a szerzők bebizonyították, hogy a gyors prototípusgyártás nehézségekkel néz szembe a vertikális, z-tengely irányú, dimenzióban. A szerzők szerint ennek hátterében sok ok lehet. Többek között a nyomtatás során a gyanta expanziója és/vagy zsugorodása, amely magyarázza az általuk talált növekvő és csökkenő tendenciákat. A szerzők végső következtetése az volt, hogy az SLA és PolyJet technológiával előállított modellek hajlamot mutatnak a függőleges sík zsugorodásának tendenciájára. 
Minden polimerizáció zsugorodással jár. A molekulák közötti van der Waals-kötések rövidebb, erősebb kovalens kötésekre cserélődnek, melyek csökkentik a polimer térfogatát. Habár a rétegezési technika csökkenti ennek a következménynek a mértékét, mégis számolni kell mikronos mérettartományba eső objektumok illeszkedése során a 3 dimenziós térfogatbeli változással. Ez a térfogatbeli változás izotrópikus jellegú és dimenzióbeli torziós faktorként jelentkezhet egy digitális munkafolyamat eredményeképpen [17].

A kísérleteinkben használt modell alapanyagok zsugorodása 7,0619 v/v\% MED620-ra és 7,9433 v/v\% MED610-re az első napon (2. táblázat). Ezek az értékek egy töltetlen akrilát típusú gyanta zsugorodásértékével összevethető értékek $[2,26]$. A PS nagyobb értéket mutatott a MED610 áttetsző anyag esetén a nyomtatás utáni első napon, mint az Vita A2 színú MED620-nál. Az eltérés oka lehet az eltérő összetétel és a töltőanyag jelenléte a MED620 modell anyagban (1. táblázat). A kompozit tömőanyagok kémiájából ismert, hogy a töltőanyaggal csökkenthető a polimerizációs zsugorodás [2, 26].

A besugárzás megszúnése után is folytatódó polimerizáció eredményezhet utólagos polimerizációs zsugorodást. Úgynevezett postpolimerizációs zsugorodást a legtöbb szerző a polimerizációt követő 24 órára vonatkoztatja. A polimerizáció előrehaladtával gyorsan nő a mátrix viszkozitása, amely kialakuló struktúrában a szabad gyökök és az el nem reagált monomerek csapdába esnek. A postpolimerizációs folyamatokban a polimerizálatlan monomerek és gyökök mozgékonyságának nagy szerepe van. A magasabb konverzióval kialakult struktúrában kisebb az esélye az előforduló szabad monomerek jelenlétének [27].

A kísérletünkben használt két, kereskedelmi forgalomban kapható 3D nyomtatható biokompatibilis polimerből készült próbatestek polimerizációs zsugorodásértékei növekedtek a nyomtatás utáni 5 napig követve. A MED610 esetén a kezdeti 7,9433 v/v\% zsugorodásérték az 5. napra $8,1704 \mathrm{v} / \mathrm{v} \%$ értékre emelkedett. Habár a 4. napon is hasonló értéket mértünk, ami arra enged következtetni, hogy egy adott értékre maximalizálódik a PS (2. táblázat). A változás mértéke $0,2271 \mathrm{v} / \mathrm{v} \%$ az öt nap alatt, amely változás a mérések szórásaival összevethetők voltak. A MED620 esetén 7,0619 v/v\%ról $7,5598 \mathrm{v} / \mathrm{v} \%$-ra nőtt a zsugorodás az 5 . napra, amely $0,4979 \mathrm{v} / \mathrm{v} \%$ eltérést jelentett az 5 . napra. Ez a változás a szórás mértékét túllépte. Ennél a modellanyagnál nagyobb mértékben nőtt a PS érték, mint a MED610 esetén, így a térfogatos változás is jelentősebb mértékű, ami hatással lehet a MED620-ból készült fogászati modellek pontosságára.

A polimerizációs zsugorodással összefüggésbe hozható polimerizációs konverzió is az általunk vizsgálni kívánt polimerizációs paraméterek közé tartozott. A DC értékek növekedtek a nyomtatás utáni 3. napig mindkét modellanyagnál. Pianelli és munkatársaihoz hasonlóan jelen tanulmány sem mutatott jelentős változást a konverziós értékekben a polimerizációt követő napokban [18]. A konverzió értékek magasak egy gyanta alapú kompozit és töltetlen gyanta konverziós értékeihez viszonyítva. Előbbi esetében átlagosan 40-50\% [30], utóbbi esetében $60-70 \%$ [21] a konverzió mértéke. A magasabb fokú polimerizáltság kevesebb szabad monomert jelent, ami hatással van az utópolimerizáció mértékére. A magasabb fokú konverziót többek között a mátrix összetétele, a besugárzás intenzitása, az alkalmazott iniciátor és a rétegvastagság is befolyásolja. Az alapanyagok szabadalmaztatott iniciátor komponenséről limitált információ áll rendelkezésre. A formulák komplex szerkezetǔek és legalább húsznál több öszszetevőt tartalmazhatnak. Az alkalmazott fényforrás UV a Polyjet technológia esetén [12]. A rétegvastagságra vonatkozóan a Stratasys az Object30 Orthodesk 3D nyomtatóknál $28 \mu \mathrm{m}$ vastag rétegekből építi fel a kinyomtatott objektumot [6,9]. Ez a kis rétegvastagság lehetővé teheti a magasabb konverzió elérését [14]. A rétegek közötti kötődés kialakulásának feltétele, hogy a határfelületen makromerek konverziójának kissé magasabbnak kell lennie a gélesedési ponttól. Ezekben a rétegekben megmaradt elreagálatlan monomerek a nyomtatási folyamat végére csak részben polimerizálnak [17]. A MED610 DC adatai magasabb értékeket mutattak, mint a MED620 esetén (3. táblázat), amely a polimer eltérő összetételével és áttetsző jellegével lehet öszszefüggésben. A polimerizáció során a fény az áttetsző polimerben akadálytalanul haladhat, egy töltött polimerrel szemben.

A polimerizációs konverzió-értékek meghatározása Fourier transzformációs Infravörös spektroszkóppal, rutinszerűen használt módszer. A csillapított teljes reflexiós (ART) módban történő mérés során az infravörös sugarak a felület néhány mikronos térfogatába hatolnak be és ezen adatok alapján történik a kiértékelés. A térfogati változást követő polimerizációs zsugorodás az ötnapos vizsgálat alatt folyamatos növekedést mutatott. A PS mérési módszer és a jelenség jellegéből adódóan a kinyomtatott objektumok teljes térfogati változásai vannak nyomon követve. A polimerizációs paraméterek közötti összefüggést megvizsgálva megállapítható, hogy a DC vizsgálatok felületi konverziós értékei eltérő változási tendenciát mutathatnak a PS értéktôl. Ennek hátterében az állhat, hogy a polimerizációs zsugorodás a mélyebb rétegekben, a tömbben történő változásokat analizálja, míg az ATR módban történt $D C$ mérések a felület néhány mikronos térfogatából gyűjt adatokat. Jelen kutatómunka távlati célja lehet a kinyomtatott objektumok szeletelése és a térfogatbeli konverzió meghatározása.

\section{Következtetések}

Méréseinkből azt a következtetést vonhatjuk le, hogy a post polimerizációs folyamatokkal további reakciók mennek végbe a mintában a nyomtatás utáni napok- 
ban, melyek hozzájárulhatnak a minta térfogatos 3 dimenzióbeli változásához. Jelen tanulmány mérése alapján elmondható, hogy $10 \mathrm{~cm}$ hosszúságú nyomtatott objektumra vonatkoztatva a MED610 esetén a zsugorodásból származtatható torzulás $22,71 \mu \mathrm{m}$, MED620 esetén 49,79 $\mu \mathrm{m}$, amely természetesen nem a valódi próbatesthez viszonyított torzulást jelent, hiszen abban még szerepet játszhat pl. a scannereknek, és a különböző tervező szoftverekben alkalmazott algoritmusoknak a hatása is. Ennek klinikai relevanciája az lehet, hogy a nyomtatás utáni utópolimerizáció, ami a zsugorodásból vagy a konverzió változásból látható, torzulást okozhat a kinyomtatott objektum dimenzióiban, s ez hatással lehet az objektum pontosságára és illeszkedésére, befolyásolva ezzel ezen anyagok fogászati alkalmazhatóságát.

\section{Köszönetnyilvánítás}

A munka a GINOP-2.3.2.-15-2016-00011, GINOP-2.3.2.-152016-00022 projektek segítségével valósult meg. A tanulmány alapjául szolgáló kutatást az Emberei Erőforrások Minisztériuma által meghirdetett Felsőoktatási Intézményi Kiválósági Program (20428-3/2018/FEKUTSTRAT) támogatta, a Debreceni Egyetem biotechnológia tématerületi programja keretében.

\section{Irodalom}

1. Bhushan $B$, Caspers $M$ : An overview of additive manufacturing (3D printing) for microfabrication. Microsyst Technol. 2017: 1117-1124.

2. Bukovinszky K, Molnár L, Bakó J, Szalóki M, Hegedus C: Folyékony kompozitok és töltetlen kompozit gyanta polimerizációs zsugorodásának összehasonlító vizsgálata. Fogorv Szle. 2014: 3-8.

3. Carve M, Wlodkowic D: 3D-Printed Chips: Compatibility of Additive Manufacturing Photopolymeric Substrata with Biological Applications. Micromach. 2018: 1-20.

4. Collares fM, Portella FF, Leitune VC, Samuel SM: Discrepancies in degree of conversion measurements by FTIR. Braz oral res. 2014: 9-15.

5. Connert T, Zehnder MS, Amato M, Weiger R, Kühl S, Krastl G: Microguided Endodontics: a method to achieve minimally invasive access cavity preparation and root canal location in mandibular incisors using a novel computer-guided technique. Int Endod J. 2018: 247-255.

6. Groth C, Kravitz ND, Jones Pe, Graham JW, Redmond WR: Three-dimensional printing technology. J Clin Orthod. 2014: 475-485.

7. http://www.stratasys.com/materials/search/biocompatible (2018.11.09.)

8. http://www.stratasys.com/sds?families=01ee8236-b1ac-4e5b -b598-1160ecff7d5b\&pageNumber=1 (2018.11.09.)

9. http://www.stratasys.com/-/media/files/printer-spec-sheets/pss pj_objet30orthodesk_0616a.pdf (2018.11.09.)

10. http://usglobalimages.stratasys.com/Main/Files/SDS/MED620 Usage_Terms_1116.pdf?v=636160085940019299 (2018.11.09.)

11. Kakami C, Nakano H, Hotta Y, Miyazaki T, Maki K: A study of bio- composite resins for creating orthodontic appliances using a 3D printer. Orthod Waves. 2017: 140-150.

12. Lee KY, Cho JW, Chang NY, Chae JM, Kang KH, Kim SC, Cho JH: Accuracy of three-dimensional printing for manufacturing replica teeth. Korean J Orthod. 2015: 217-225.

13. LeE WS, LeE DH, LeE KB: Evaluation of internal fit of interim crown fabricated with $\mathrm{CAD} / \mathrm{CAM}$ milling and $3 \mathrm{D}$ printing system. J Adv Prosthodont. 2017: 265-270.

14. Lempel E, Czibulya Zs, Kunsági-Máté S, Szalma J, Sümegi B, BödDI K: Quantification of Conversion Degree and Monomer Elution from Dental Composite Using HPLC and Micro-Raman Spectroscopy. Chromatographia. 2014: 1137-1144.

15. Leonhardt S, Klare M, Scheer M, Fischer T, Cordes B, Eblenkamp M: Biocompatibility of photopolymers for additive manufacturing. Cur Direc Biomed Eng. 2016: 113-116.

16. LIGON SC, LISKA R, Stampfl J, GuRR M, Mulhaupt R: Polymers for 3D Printing and Customized Additive Manufacturing. Chem Rev. 2017: 10212-10290.

17. Melchels FP, Feijen J, GriJPma DW: A review on stereolithography and its applications in biomedical engineering. Biomat. 2010: 6121-6130.

18. Pianelli C, Devaux J, Bebelman S, Leloup G: The micro-Raman spectroscopy, a useful tool to determine the degree of conversion of light-activated composite resins. J Biomed Mater Res. 1999: 675-681.

19. Porto BG, Porto TS, Silva MB, Grehs Ra, Pinto Ados S, BhanDI $\mathrm{SH}$, et al.: Comparison of linear measurements and analyses taken from plaster models and three-dimensional images. $J$ Contemp Dent Pract. 2014: 681-687.

20. Rebong Re, Stewart KT, Utreja A, Ghoneima AA: Accuracy of three-dimensional dental resin models created by fused deposition modeling, stereolithography, and Polyjet prototype technologies: A comparative study. Angle Orthod. 2018: 363-369.

21. Schroeder WF, Vallo Cl: Effect of different photoinitiator systems on conversion profiles of a model unfilled light-cured resin. Dent Mater. 2007: 1313-1321.

22. Shaheen E, Alhelwani A, Van De Casteele E, Politis C, Jacobs R: Evaluation of Dimensional Changes of 3D Printed Models After Sterilization: A Pilot Study. Open Dent J. 2018: 72-79.

23. Shaaidef A, Ayoub AF, Khambay BS: How accurate are rapid prototyped (RP) final orthognathic surgical wafers? A pilot study. Br J Oral Maxillofac Surg. 2014: 609-614.

24. Stansbury JW, IDACAVAGE MJ: 3D printing with polymers: challenges among expanding options and opportunities. Dent Mater. 2016: 54-64.

25. Strbac GD, Schnappauf A, Giannis K, Bertl MH, Moritz A, Ulm C: Guided Autotransplantation of Teeth: A Novel Method Using Virtually Planned 3-dimensional Templates. J Endod. 2016: 18441850.

26. Szaloki M, Gall J, Bukovinszki K, Borbely J, Hegedus C: Synthesis and characterization of cross-linked polymeric nanoparticles and their composites for reinforcement of photocurable dental resin. React Funct Polym. 2013: 465-473.

27. Truffier-Boutry D, Demoustier-Champagne S, Devaux J, Biebuyck JJ, Mestdagh M, Larbanois P, Leloup G: A physico-chemical explanation of the post-polymerization shrinkage in dental resins. Dent Mater. 2006: 405-412.

28. VAN NoORT R: The future of dental devices is digital. Dent Mater. 2012: 3-12.

29. Wesemann C, Muallah J, Mah J, Bumann A: Accuracy and efficiency of full-arch digitalization and 3D printing: A comparison between desktop model scanners, an intraoral scanner, a СBCT model scan, and stereolithographic 3D printing. Quintessence Int. 2017: 41-50.

30. Yoon TH, LeE YK, LIM BS, KIM CW: Degree of polymerization of resin composites by different light sources. J Oral Rehabil. 2002: 1165-1173. 
Szalókı M, Javadı H, Khandan S, Youssef A, Gáll J, Hegedüs Cs

\section{Investigation of polymerization properties of 3D printable biocompatible polymers}

The development of digital technology is more and more meaningful on the area of dentistry. There are many factors that influence the accuracy of 3D printing among others composition of polymers for printing, that determine the polymerization parameters such as polymerization shrinkage (PS) and degree of conversion (DC). These factors have an important role in the postpolymerization process that have an effect on accuracy of 3D printing and torsional parameters. Aim of this study was to analyse the polymerization parameters (PS and DC) of MED610 and MED620 (Stratasys, USA) during five-day period after the printing. Based on our measurements it was found that PS values were increased from 7,9433 vol\% to 8,1704 vol\% at MED610 and from 7,0619 vol\% to 7,5598 vol\% at MED620 during the five days period. The DC values were between 90,182 and $99,9433 \%$ and showed the maximum at third day. The polymerization parameters showed significant differences between the first day and fifth day measurements. Based on data of this study it can established that distortion error of MED610 is 22,71 $\mu \mathrm{m}$ and 49,79 $\mu \mathrm{m}$ at MED620 from polymerization shrinkage regarding a $10 \mathrm{~cm}$ length printed object. This values do not mean a distortion relative to the parameters of the real specimen, since in it e.g. scanners, and different design software of algorithms can still play a role. The clinical relevance is that the postpolymerization can cause distortion that effect is more relevant than has effect on the accuracy of the printed object to influence the dental application of these materials.

Keywords: MED610, MED620, 3D printable biocompatible polymer, polymerization shrinkage, degree of conversion, postpolymerization, PolyJet. 